\title{
Reproductive biology of three gadiform fish species through the Mediterranean deep-sea range $(147-1850 \mathrm{~m}) *$
}

\author{
GUIOMAR ROTLLANT ${ }^{1}$, JOAN MORANTA ${ }^{2}$, ENRIC MASSUTÍ ${ }^{3}$, FRANCISCO SARDÀ ${ }^{1}$ \\ and BEATRIZ MORALES-NIN² \\ ${ }^{1}$ Institut de Ciències del Mar (ICM/CSIC), CMIMA, Passeig Marítim de la Barceloneta 37-49, E-08003 Barcelona, Spain. \\ E-mail: guio@icm.csic.es \\ ${ }^{2}$ Institut Mediterrani d'Estudis Avançats (CSIC-UIB), Miguel Marqués 21, E-07190 Palma de Mallorca, Spain. \\ ${ }_{3}^{3}$ IEO-Centre Oceanogràfic de les Balears, Moll de Ponent s/n, P.O. Box 291, 07080 Palma de Mallorca, Spain.
}

\begin{abstract}
SUMMARY: Knowledge of deep-sea reproductive biology is slight and interpretations of reproductive strategies in deepsea fishes are controversial. Since the Mediterranean is a fairly stable and constant sea, we might expect a consistent pattern of reproduction of deep-sea species. Three gadiforms species with a succesive bathymetric and an ecological and economical importance in the Mediterranean fishing industry, Phycis blennoides, Mora moro and Lepidion lepidion, were selected for the present study. These three species of gadiforms are sexually dimorphic and their reproductive population is located at the lower zone of their bathymetric range. Females were always bigger than males. The smallest mature male was observed at 19,32 and $18 \mathrm{~cm}$ TL (total length) and the smallest mature female at 20, 34 and $20 \mathrm{~cm}$ TL for P. blennoides, $M$. moro and L. lepidion respectively. The three species are iteroparous and females could be all-at-once or batch-spawners. An autumn mature season was observed for P. blennoides, whereas M. moro and L. lepidion had mature individuals all year round except in summer. Hence, physical constancy at greater depths is able to lengthen the reproductive season and the deepest species has a quasi-continuous reproductive pattern. Similar reproductive tissues have been found in the three species studied, and they show analogous structure with other deep-sea gadiforms and their shallow-water congeners.
\end{abstract}

Key words: biology, reproduction, gadiform, deep-sea, Mediterranean.

\section{INTRODUCTION}

The reproductive pattern of deep-sea species was considered continuous for many years on the basis of the physico-chemical stability of the deepsea (Orton, 1920). Nevertheless, research undertaken in the last three decades into the biology of exploited deep-sea fish in Australia (Koslow et al., 1995), New Zealand (Clark, 1995), the North

\footnotetext{
*Received January 1, 2001. Accepted October 8, 2001
}

Atlantic (Atkinson, 1995; Kelly et al., 1996; Coggan et al., 1999; Allain, 2001), the North Sea (Bergstad, 1990), Greenland (Bowering and Brodie, 1995; Albert et al., 2001; Gundersen et al., 2001) and Iceland (Magnússon and Magnússon, 1995; Magnússon, 2001) demonstrates that most of the fish species studied have seasonal spawning. The timing and duration of the spawning peak and the maturity age vary with the different species, the area of distribution of each species and the depthrange of the species in each area. 
Seasonal reproduction in deep-sea species would not be controlled by light and temperature, as occurs in many shallow-water species (cf. Helfman et al., 1997), but could be controlled by food availability, through organic matter sinking, deep ocean currents or vertical migrations (Gage and Tyler, 1991; Grassle, 1994; Tyler et al., 1994; Young and Eckelbarger, 1994).

In particular, the Mediterranean Sea is physically fairly constant: isothermal below $200 \mathrm{~m}\left(\sim 13{ }^{\circ} \mathrm{C}\right)$, with high salinity, low oxygen and oligotrophy (Hopkins, 1984). Despite this constancy, the reproduction pattern in Mediterranean deep-sea species is still controversial. Morales-Nin et al. (1996) observed continuous spawning with a peak in autumn for Alepocephalus rostratus, while D’Onghia et al. (1999, 2000) and Massutí et al. (1995) found either seasonal or continuous spawning in different species of macrourids.

In the present study we selected three gadiform species, Phycis blennoides (Brünnich, 1768), Mora moro (Risso, 1810) and Lepidion lepidion (Risso, 1820), because they show successive bathymetric distribution along the upper, middle and lower slope, and share morphological and ecological characteristics (Gallardo, 1980; Massutí et al., 1996; Stefanescu et al., 1992; Moranta et al., 1998). Moreover, P. blennoides is already the object of important fishery exploitation in the Catalan Sea (Massutí et al., 1996). Although M. moro and L. lepidion are not yet exploited in the Mediterranean because the commercial trawling is mainly restricted to a depth shallower than $700 \mathrm{~m}$, the decline of traditional fisheries on the continental shelf and the improvement of trawling systems towards greater depths might support a potential fishery of these species in the Mediterranean Sea. However, prior to an establishment of a new fishery, it will be necessary to improve biological studies, mainly in reproduction, to avoid overexploitation as occurred in other deep-sea species (Koslow et al., 2000; Clark, 2001).

There are several papers concerning the bathymetric distribution and biology of the gadiform species in the western Mediterranean (Morales-Nin, 1990, Stefanescu et al., 1992a, 1992b; Massutí et al., 1995; Carrassón et al., 1997; Moranta et al., 1998), but there is a lack of information concerning their reproduction. P. blennoides spawning and recruitment were studied in the Ionian Sea (EasternCentral Mediterranean) and a restricted reproduction season of about 3-4 months in late autumn-early winter was found (Matarrese et al., 1998). Although

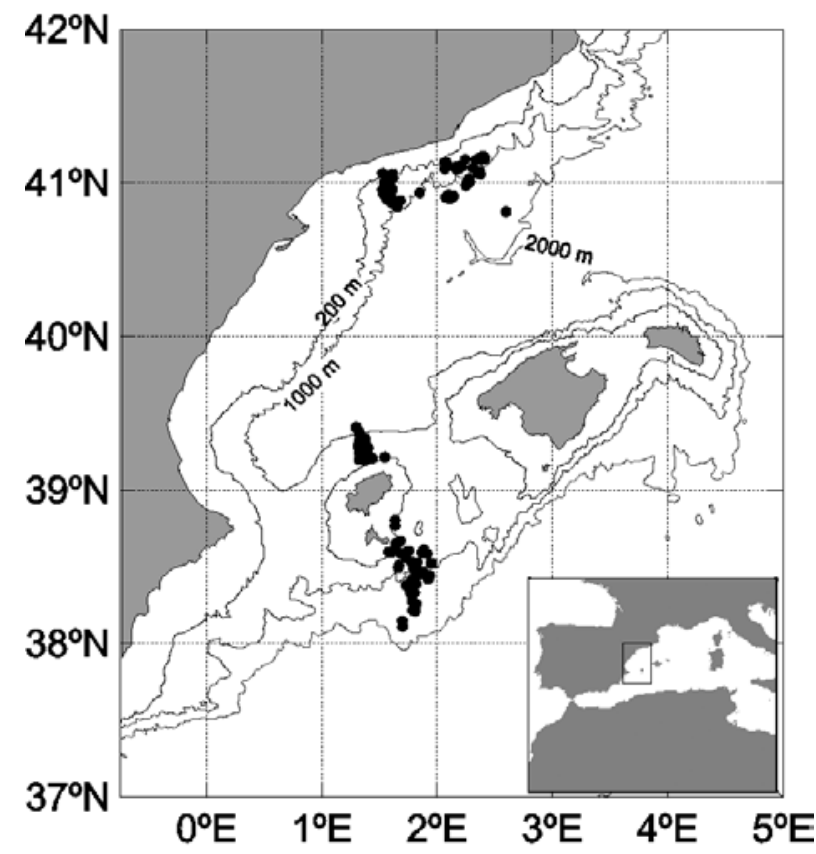

FIG. 1. - Map of the Balearic Sea (western Mediterranean) showing the sampling stations (black dots).

some previous studies have suggested autumn recruitment due to a minor spring spawning peak (Lo Bianco, 1909; Cohen et al., 1990; D’Onghia et al., 1998), the important peak in reproduction in the species occurs in autumn-winter (Matarrese et al., 1998). There are no data for the deeper dwelling species M. moro and L. lepidion.

The aims of this study are to describe the reproduction pattern of three gadiform Mediterranean deep-sea species: Phycis blennoides, Mora moro and Lepidion lepidion, in terms of their population structure, seasonal pattern and bathymetric distribution.

\section{MATERIAL AND METHODS}

Samples were collected by research vessels from April 1991 to May 1998 and in fishing vessels from April to October 1997 in the Balearic sea around Ibiza Island and off the Catalan coast (approximately $2^{\circ} \mathrm{E} 40^{\circ} \mathrm{N}$, Fig. 1) from trawls carried out between 147 and 1850 metres (Table 1). Since deep-sea fishing is very complicated and expensive, samples belonging to different cruises were necessary in order to have a representative number of data, and therefore data were processed together.

A total of 3816 P. blennoides, 716 M. moro and 2524 L. lepidion were caught. On board, total length (TL) and standard length (SL) were measured to the $\mathrm{cm}$ below, and weighed to the nearest $1 \mathrm{~g}$ (Table 2). 
TABLE 1. - Data on the sampling cruises analysed in this study. *Sampling: twice a month. ${ }^{1}$ Sardà et al., 1994, ${ }^{2}$ Rucabado et al., 1991.

\begin{tabular}{llccc}
\hline Cruises & Date & Depth range $(\mathrm{m})$ & Number of hauls & Trawl gear \\
\hline RETRO I & 23-26 April 1991 & $378-1258$ & 9 & OTMS-27.5 $^{1}$ \\
RETRO II & 7-10 December 1991 & $433-1850$ & 10 & OTMS-27.5 $^{-10}$ \\
RETRO III & 12-13 March 1992 & $355-1276$ & 9 & OTMS-27.5 \\
ZONAP0592 & 22-30 May 1992 & $147-1150$ & 39 & OTSB-14 \\
RETRO IV & 26-28 July 1992 & $434-1293$ & 9 & OTMS-27.5 \\
BATMAN I & 15-19 March 1994 & $650-1230$ & 25 & OTMS-27.5 \\
QUIMERA I & 15-30 October 1996 & $264-1715$ & 32 & OTMS-27.5 \\
QUIMERA II & 5-12 May 1998 & $195-1622$ & 14 & OTMS-27.5 \\
Fishing vessels* & 28 April-21 October 1997 & $432-684$ & & Commercial \\
\hline
\end{tabular}

TABLE 2. - Sample collection of the three gadiform species studied. $I=$ indeterminate, $F=$ females, $M=$ males.

\begin{tabular}{|c|c|c|c|c|c|c|}
\hline & \multirow[t]{2}{*}{$\begin{array}{l}\text { Number of } \\
\text { fish measured }\end{array}$} & \multicolumn{3}{|c|}{$\begin{array}{l}\text { Number of gonad } \\
\text { macroscopic observations }\end{array}$} & \multicolumn{2}{|c|}{$\begin{array}{l}\text { Number of gonad } \\
\text { histological observations }\end{array}$} \\
\hline & & I & $\mathrm{F}$ & M & $\mathrm{F}$ & $\mathrm{M}$ \\
\hline Phycis blennoides & 3816 & 213 & 255 & 243 & 38 & 9 \\
\hline Mora moro & 716 & 35 & 305 & 178 & 22 & 10 \\
\hline Lepidion lepidion & 2524 & 188 & 269 & 131 & 20 & 0 \\
\hline
\end{tabular}

Their stage of maturity was determined by macroscopic examination of the gonads following the four-point scale (1: immature, 2: early maturation stage, 3: advanced maturation stage, 4: ripe) and gonads were weighed to the nearest $0.1 \mathrm{~g}$. The sex ratio for each size range was tested using a $\chi^{2}$-test (Statistica 4.5) with a probability of $\mathrm{p}<0.05$.

On board, 298 gonads were fixed in $10 \%$ formaldehyde for $48 \mathrm{~h}$, rinsed in water and stored in $70 \%$ ethanol. For the histological analysis a subsample of 99 specimens (TL> $40 \mathrm{~cm}$ for $P$. blennoides and M. moro, and TL> $30 \mathrm{~cm}$ for L. lepidion) was taken on the basis of the fishes' gonadosomatic index (calculated by dividing the sum of the components of the gonads by the body weight and multiplying by 100) and the gonad macroscopic observation. A small piece of tissue from the middle of the right gonad was taken. The pieces of the selected ovaries and testes were dehydrated in an ethanol series and embedded in Historesin (Leica). Sections $(3 \mu \mathrm{m})$ were cut by a Reichert-Jung Microtome and stained with hematoxyline-eosine or periodic acid Schiff.

Over 100 oocytes from each reproductive stage of the three species were measured and counted using an OPTIMAS 6.0 analyser at a magnification of $\mathrm{x} 40, \mathrm{x} 100$ or $\mathrm{x} 200$ depending on the stage of development of the gonads. Cell density was calculated by Munk's formula (1965) modified by Meer and Anker (1984):

Cell density $=10^{6} * \mathrm{~m}[(\mathrm{t}+\mathrm{d}-2 \mathrm{f}) * \mathrm{~W}]^{-1}$ cells $/ \mathrm{mm}^{2}$ where $\mathrm{m}$ is the mean number of cells counted, $\mathrm{t}$ is the section thickness, $d$ is the mean diameter of the cells, $\mathrm{f}$ is the thickness of the smallest cell fragments counted $\left(f=0.1^{*} d\right)$ and $w$ is the width of the sampled strip.

\section{RESULTS}

The samples used in this study for the three gadiform species were distributed successively down the continental slope from $147 \mathrm{~m}$ to $1850 \mathrm{~m}$ (Fig. 2). The length frequency distributions of the three species studied are shown in Figure 3. P. blennoides is the biggest species and shows only one modal group while $M$. moro and L. lepidion have two and three modal groups respectively. Females always attained a longer size than males. The smallest

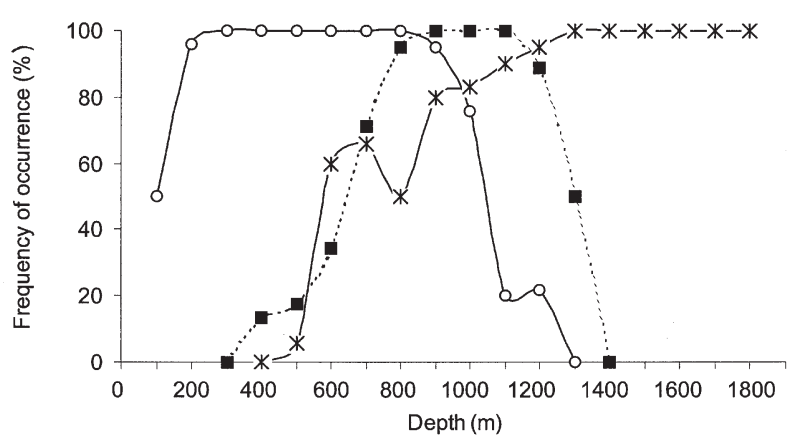

FIG. 2. - Bathymetric distribution of frequency of appearance for Phycis blennoides (empty circles) Mora moro (full squares) and Lepidion lepidion (asterisks). 

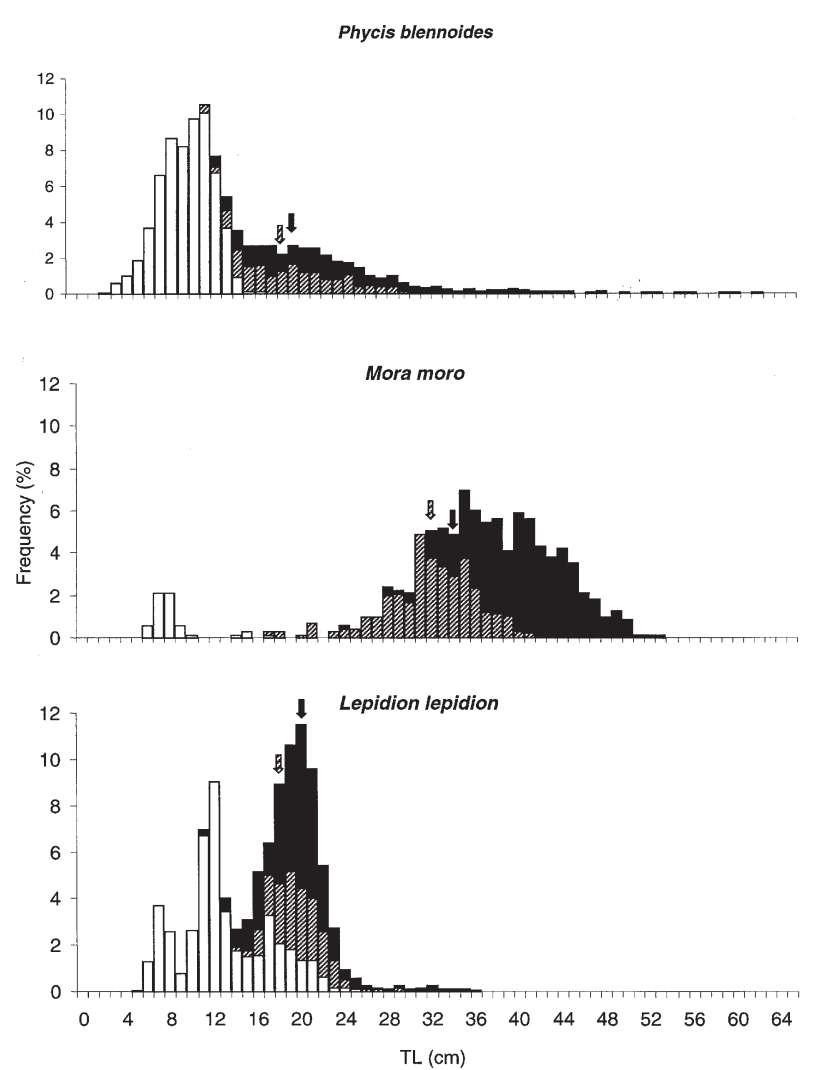

FIG. 3. - Phycis blennoides, Mora moro and Lepidion lepidion length frequency distributions and sex ratios. Open columns $=$ sex indeterminate, hatched columns $=$ males, solid columns $=$ females, hatched arrow $=$ smallest mature male observed and solid arrow $=$ smallest mature female observed.

mature male was observed at 19,32 and $18 \mathrm{~cm}$ TL and the smallest mature female at 20,34 and $20 \mathrm{~cm}$ TL for P. blennoides, M. moro and L. lepidion respectively. The mean size of the three studied species increases with depth (Fig. 4).

$P$. blennoides females only had mature stages in autumn, while mature males were found from summer to early autumn. Mature females of M. moro and $L$. lepidion were found all year round except in summer. M. moro mature males were found in autumn and spring and L. lepidion mature males in autumn and winter (Fig. 5). The mature individuals were situated at the lower depth of the bathymetric range of $P$. blennoides and at intermediate depth in the case of $L$. lepidion. Mature specimens of $M$. moro were observed in all its depth distribution, but individuals with mature gonads were only observed at the lower range (Fig. 6).

The results of the gonad histological study are very similar, so a common description for the three species could be made. Gonads were internal, longitudinal, paired and laid along the gas bladder. The lengths of both gonads were very similar. No histo-
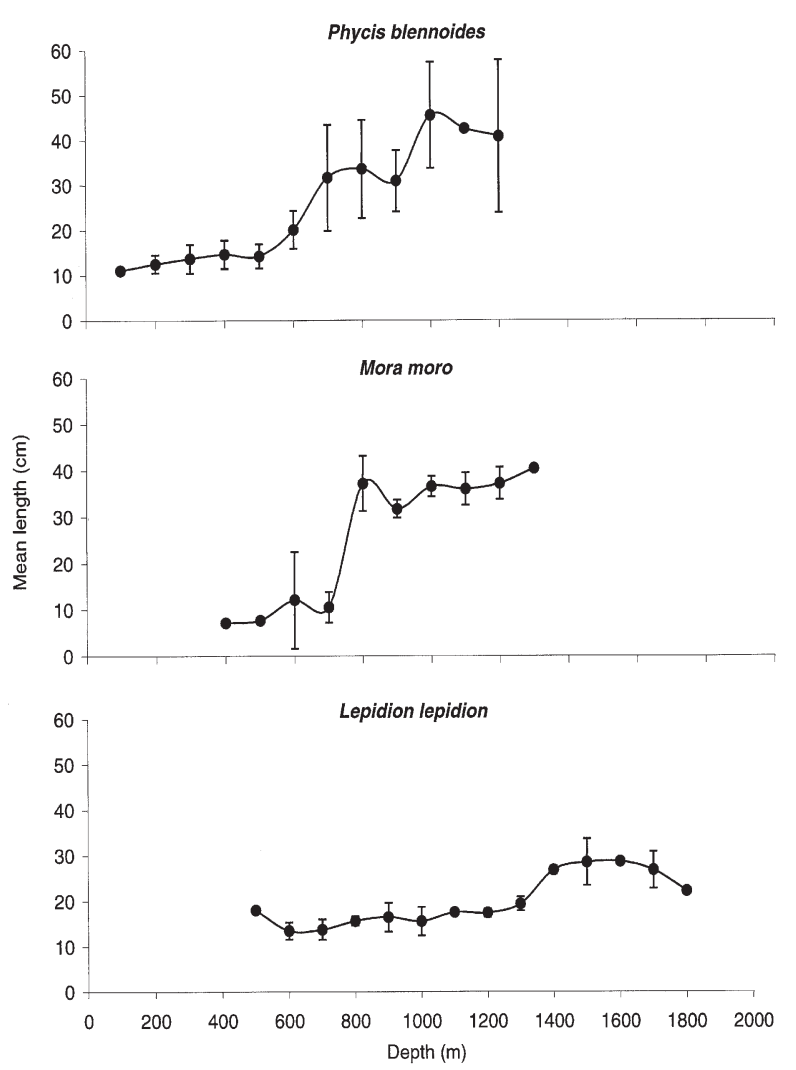

FIG. 4. - Mean length distribution of Phycis blennoides, Mora moro and Lepidion lepidion by depth. Bars represent standard deviation.

logical differences were observed between the left and right gonads or between the anterior and posterior parts of the gonads.

Technical problems made it impossible to study L. lepidion testes. P. blennoides and M. moro had testes with white lobular structure, which grew throughout development. Immature testes showed a rich connective tissue with no reproductive cells visible yet (Fig. 7a). When mature, the testes were well organised in lobes with each lobe surrounded by connective tissue. Each lobe contained several cysts with germ cells at different stages of spermatogenesis (Fig. 7b). One specimen of P. blennoides had oocytes in its testis (Fig. 7c).

The histological characteristics of the ovaries enabled us to determinate four maturity stages for the three species of gadiforms:

- Stage I. Immature: the oogonia and oocytes I and II were present. The oocyte I had a large nucleus surrounded by a thin cytoplasm with an intense basophilic substance. This nucleus increased in size and multiple nucleoli appeared generally at its periphery, and then it was named oocyte II.

These ovaries corresponded to slender whitetranslucent thread. 

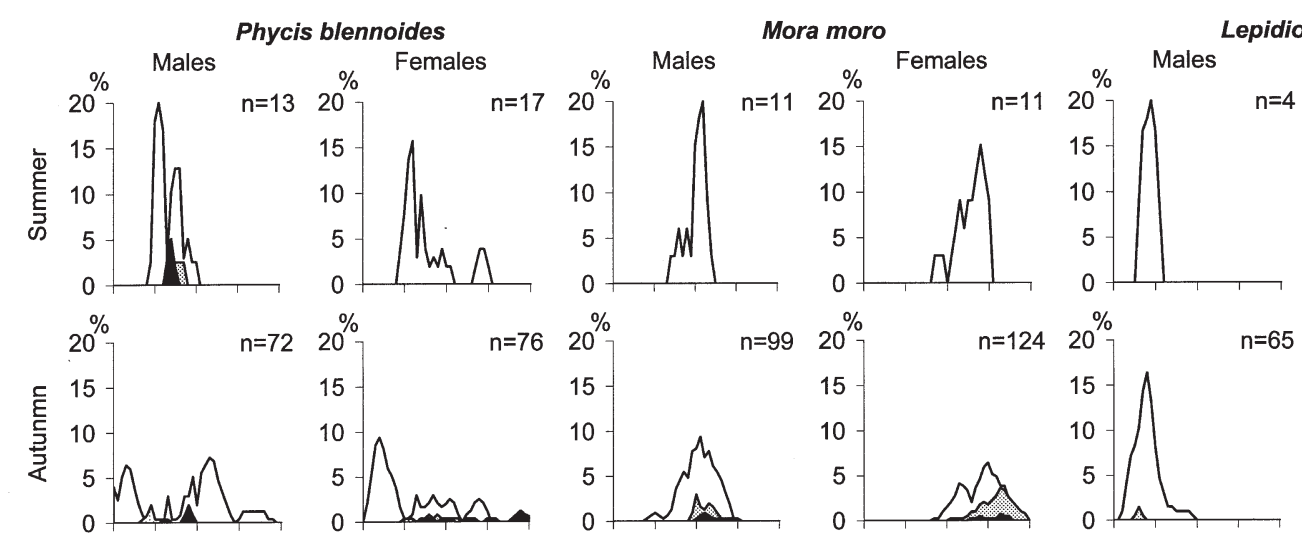

Lepidion lepidion
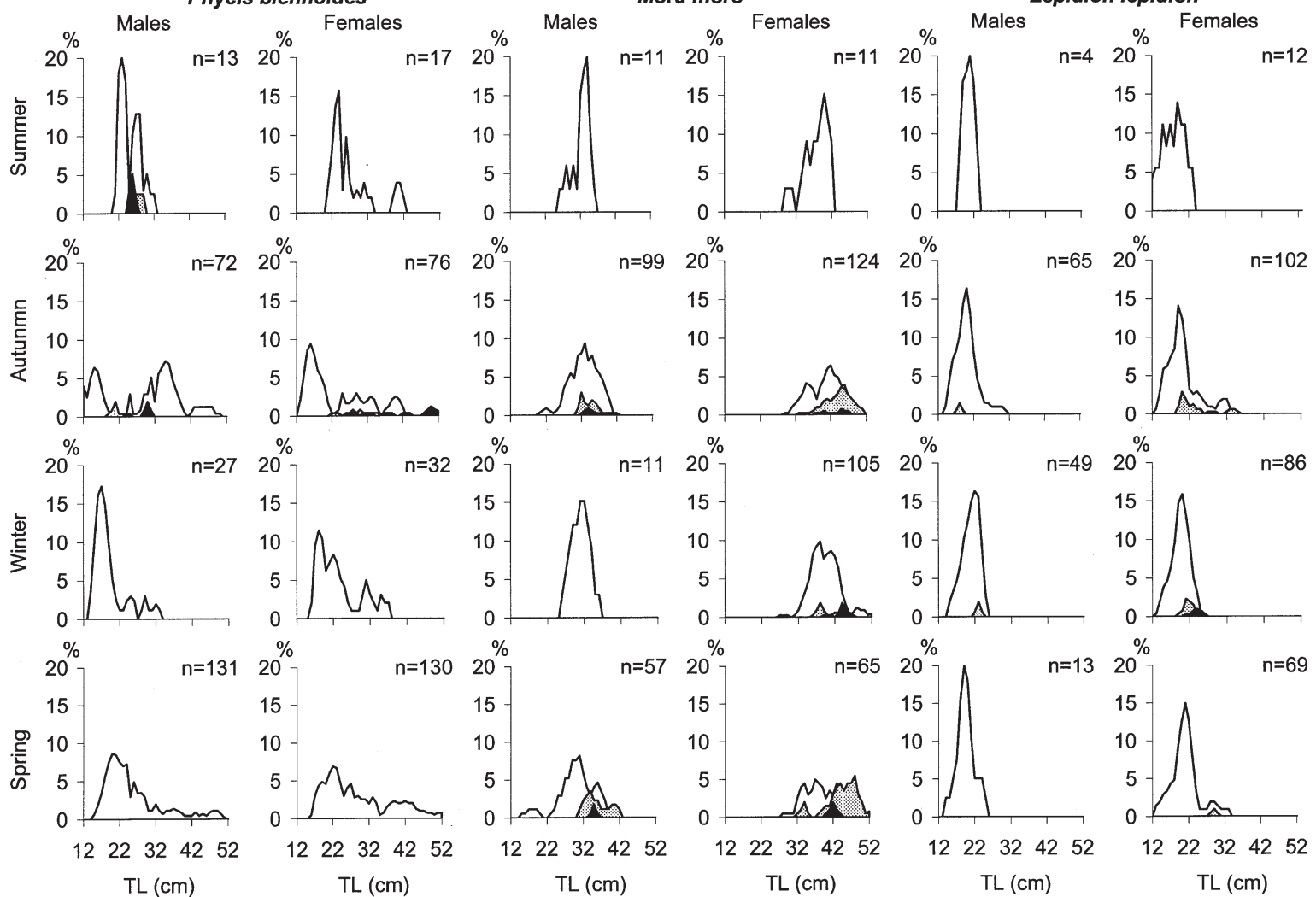

FIG. 5. - Size frequency of males and females and maturity stage in each season by species: Phycis blennoides, Mora moro and Lepidion lepidion. White = immature $($ stage 1,2$)$, grey $=$ mature $($ stage 3$)$ and black $=$ mature $($ stage 4$)$.

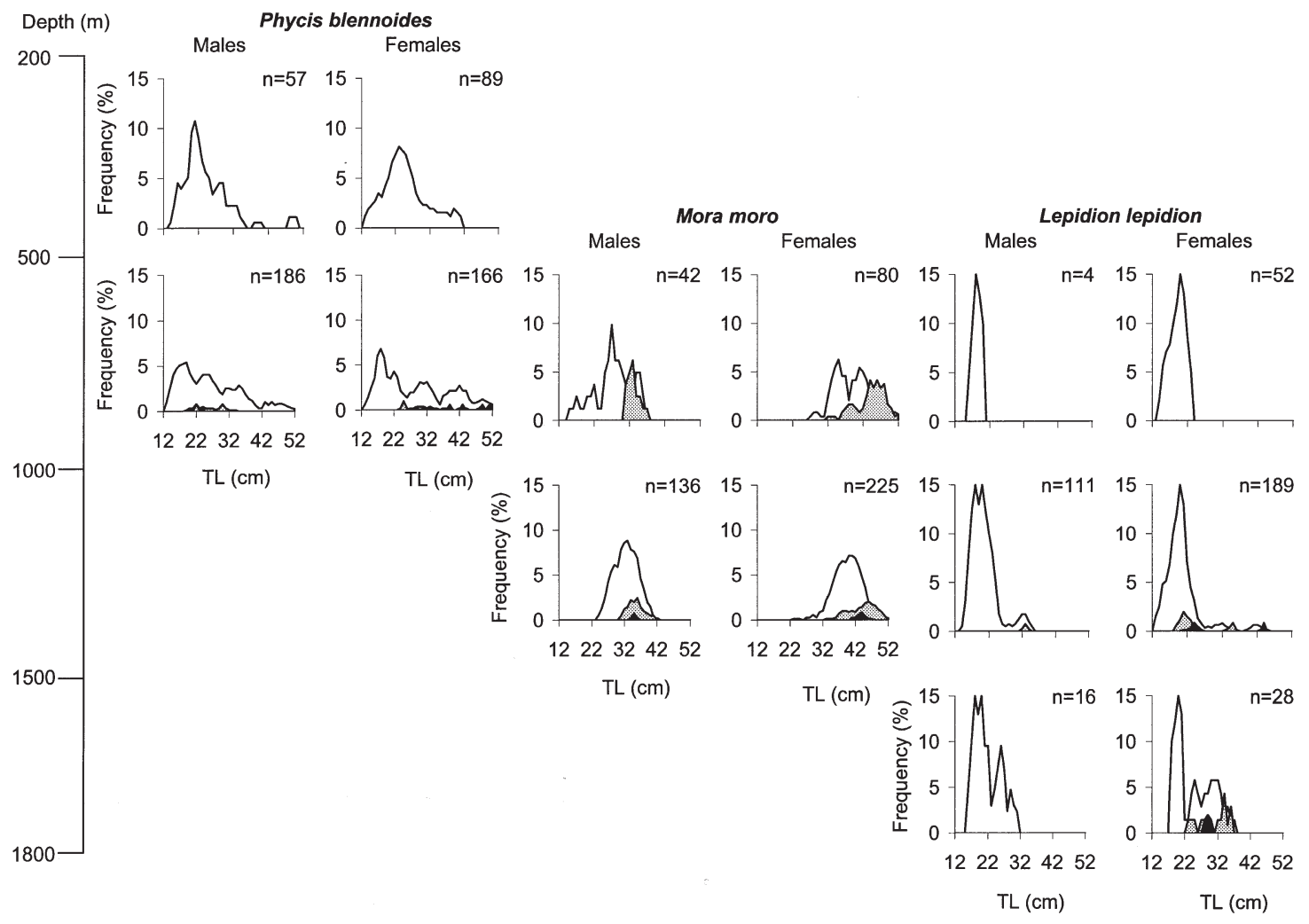

FIG. 6. - Size frequency of males and females and maturity stage by species (Phycis blennoides, Mora moro and Lepidion lepidion) at different depth intervals. White $=$ immature $($ stage 1,2$)$, grey $=$ mature $($ stage 3$)$ and black $=$ mature $($ stage 4$)$. 

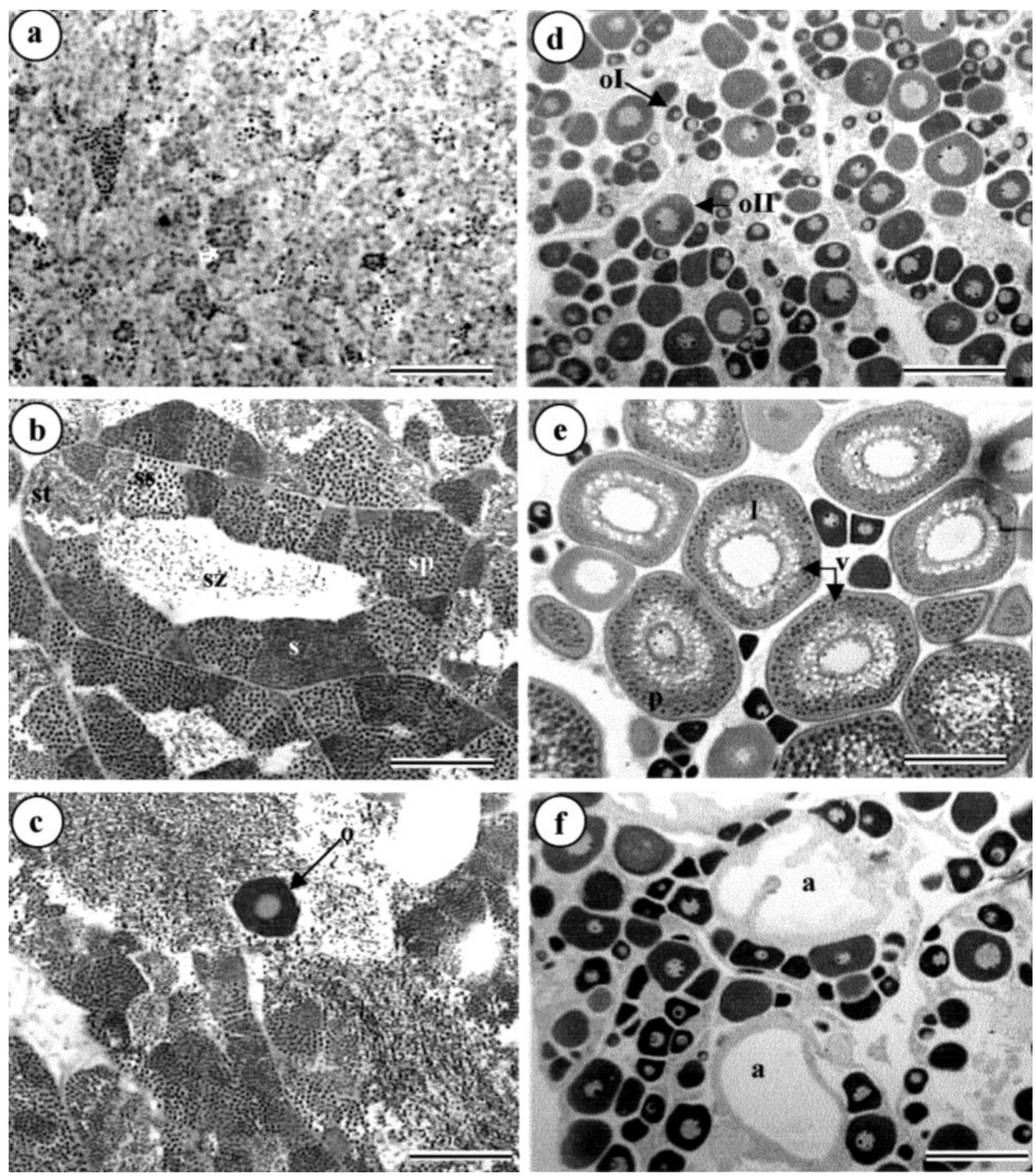

FIG. 7. - Histological sections of gonads: a) Immature male of Phycis blennoides, b) Mature male of Phycis blennoides, s = spermatogonia, ps = primary spermatocyte, $\mathrm{ss}=$ secondary spermatocyte, $\mathrm{st}=$ spermatids, sz = spermatozoa, c) Intratesticular oocyte (o) in a male of Phycis blennoides, d) Immature female (stage II) of Mora moro, oI = primary oocyte, oII = secondary oocyte, e) Mature female (stage IV) of Mora moro, l = lipid vesicles, $\mathrm{p}=$ protein vesicles, v = vitellogenic oocyte, and f) Atresia (a) in stage II ovaries of Lepidion lepidion.

- Stage II. Early developing: distinguished by the presence previtellogenic oocytes characterised by a large cytoplasm because of the development of the cytoplasmatic organelles. Oocytes I and II were present as well.

The ovaries were a small orange-pink tube.
- Stage III. Late developing: distinguished by the presence of lipid vesicles that constitute the previtellogenetic oocyte II. Oocytes I and II and previtellogenic oocytes I were present as well.

The ovaries were a long orange-red tube. 
TABle 3. - Cell characteristics of the ovaries of Phycis blennoides (Pb), Mora moro (Mmo) and Lepidion lepidion (Ll): Density and percentage of the different cell types in each maturity stage.

\begin{tabular}{|c|c|c|c|c|c|c|c|c|c|}
\hline Species & Stage & $\begin{array}{c}\text { Density } \\
(\text { cells/mm²) }\end{array}$ & Oogonia & Oocyte I & Oocyte II & $\begin{array}{l}\text { Previtellogenic } \\
\text { oocyte I }\end{array}$ & $\begin{array}{l}\text { Previtellogenic } \\
\text { oocyte II }\end{array}$ & $\begin{array}{l}\text { Vitellogenic } \\
\text { oocyte }\end{array}$ & Indeterminates \\
\hline $\mathrm{Pb}$ & $\begin{array}{l}\text { I } \\
\text { IV }\end{array}$ & $\begin{array}{l}2.95 \times 10^{11} \\
1.10 \times 10^{9}\end{array}$ & $6.52 \%$ & $\begin{array}{l}3.20 \% \\
1.42 \%\end{array}$ & $\begin{array}{l}40.37 \% \\
14.17 \%\end{array}$ & $10.31 \%$ & $31.31 \%$ & $23.58 \%$ & $\begin{array}{l}49.91 \% \\
19.20 \%\end{array}$ \\
\hline Mmo & $\begin{array}{l}\text { II } \\
\text { III } \\
\text { IV }\end{array}$ & $\begin{array}{l}2.28 \times 10^{10} \\
9.00 \times 10^{10} \\
7.67 \times 10^{9}\end{array}$ & & $\begin{array}{l}2.68 \% \\
5.32 \% \\
4.72 \%\end{array}$ & $\begin{array}{l}23.96 \% \\
18.09 \% \\
24.53 \%\end{array}$ & $\begin{array}{l}41.57 \% \\
37.77 \% \\
26.41 \%\end{array}$ & $\begin{array}{l}7.98 \% \\
5.66 \%\end{array}$ & $5.97 \%$ & $\begin{array}{l}31.79 \% \\
30.85 \% \\
32.70 \%\end{array}$ \\
\hline $\mathrm{Ll}$ & II & $1.87 \times 10^{10}$ & & $2.42 \%$ & $34.54 \%$ & $25.22 \%$ & & & $37.82 \%$ \\
\hline
\end{tabular}

TABLE 4. - Diameter of the ovarian cells $(\mu \mathrm{m})$ of Phycis blennoides $(\mathrm{Pb})$, Mora moro $(\mathrm{Mmo})$ and Lepidion lepidion (Ll).

\begin{tabular}{lccrrrr}
\hline Species & Oogonia & Oocyte I & Oocyte II & Previtellinic oocyte I & Previtellinic oocyte II & Vitellinic oocyte \\
\hline $\mathrm{Pb}$ & \multirow{2}{*}{$20.25 \pm 3.72$} & $39.47 \pm 9.49$ & $45.95 \pm 14.69$ & $142.34 \pm 18.02$ & $195.36 \pm 40.34$ & $305.08 \pm 64.43$ \\
$\mathrm{Mmo}$ & & $33.19 \pm 11.11$ & $51.27 \pm 14.75$ & $86.80 \pm 24.83$ & $207.54 \pm 33.77$ & $249.59 \pm 19.31$ \\
$\mathrm{Ll}$ & & $24.95 \pm 2.12$ & $58.43 \pm 21.19$ & $76.41 \pm 21.78$ & & \\
\hline
\end{tabular}

- Stage IV. Gravid: distinguished by the presence of protein yolk granules that constitute the vitellogenetic oocytes which occupy most of the ovary. Oocytes I and II, previtellogenic oocytes I and II, and vitellogenetic oocytes were present as well.

The characteristics of the ovarian cells for each species are shown in Table 3 and 4. Cell density decreased as the gonads matured. In stage IV of maturity all ovarian cell types occurs but oogonia, and the percentage of previtellogenic oocytes II and vitellogenic oocytes were 4 times greater in $P$. blennoides than in M. moro. L. lepidion presented the smallest oocytes I and P. blennoides the largest vitellogenic oocytes. P. blennoides and M. moro had immature (Fig. 7d) and well-developed ovaries (Fig. 7e). L. lepidion only had females in stage II: high atresia was observed in their ovaries (Fig. 7f). No hydrated oocyte was observed for any species.

\section{DISCUSSION}

P. blennoides, the shallowest species studied (maximum frequency of appearance between 200 and $800 \mathrm{~m}$ in this study), reached maturity in autumn while the deepest species M. moro (800$1200 \mathrm{~m}$ ) and L. lepidion (1000-1800 m) had mature individuals all year round except for summer. Hence, for these species the physical constancy at greater depths in the Mediterranean deep-sea is able to lengthen the reproductive season supporting Orton's hypothesis.
The maturing period observed for $P$. blennoides confirms the spawning period proposed for this species in the Mediterranean from January to March (Svetovidov, 1986; Cohen et al., 1990; Massutí et al., 1996). In the Ionian Sea, mature females were caught from November to January and mature males between August and March (Matarresse et al., 1998). In the western Mediterranean the mature males appear a longer period of time from May to November, while mature females were only seen in autumn. Gordon and Duncan (1985) suggested that spawning of $M$. moro in the Rockall Trough is in June or July, while Cohen (1986) indicated that $M$. moro in the Mediterranean is probably a winter or early spring spawner. No reproduction data about $L$. lepidion have been found in the literature. In the Rockall Trough Lepidion eques had a seasonal reproductive cycle with spawning in April and May (Gordon et al., 1979).

In the Mediterranean, other gadifirm species living in the upper-middle slope can present a continuous reproductive pattern as in Nezumia sclerorhynchus (D’Onghia et al., 1996, 1999, 2000), N. aequalis (Massutí et al., 1995) and Hymenocephalus italicus (Massutí et al., 1995; D’Onghia et al., 1996), a quasi-continuous strategy with a reproductive peak as in Coelorhynchus coelorhynchus (Massutí et al., 1995; D’Onghia et al., 1996, 1999,), or a seasonal pattern as in Trachyrhynchus trachyrhynchus (D'Onghia, 1996). The lower slope macrourid studied, Coelorhynchus labiatus, has an autumn-winter spawning (Massutí et al., 1995). The 
other deep-sea species studied in the area, A. rostratus, with a depth distribution in the lower middle slope, has a high reproductive activity all year round with a peak in autumn (Morales-Nin et al., 1996). The overview about reproductive biology of deepsea fishes in the Mediterranean cited above and the reproductive studies performed all over the world in deep-sea gadiform species (Bergstad, 1990; Clark, 1995; Koslow et al., 1995; Albert et al., 2001; Allain, 2001; Gundersen et al., 2001; Magnússon, 2001) demonstrate that in this zoological group spawning varies with the different species and their area of distribution. Hence, it is not possible to identify a reproductive tendency for these species. Following Tyler et al. (1994) and Grassle (1994), the reproductive strategy should be related to changes in feeding. Recently, high concentrations of suspended particles have been related to reproductive processes and the spatial distribution of deep-water benthic shrimps (Puig et al., 2001). Nevertheless, no seasonal changes in the diet composition of $P$. blennoides have been noted (Macpherson, 1978).

The three studied species, $P$. blennoides, $M$. moro and $L$. lepidion are dimorphic in size (females larger than males) with sex ratios weighted in favour of females. This can be explained because many slopedwelling fish females become mature when they are reaching their maximum total length and somatic growth slows down (Gordon et al., 1995). M. moro and $L$. lepidion have several modal peaks of length. The first mature specimen had a total length corresponding to the beginning of the last peak, as in Coryphaenoides rupestris (Merrett and Haedrich, 1997). Also in the case of P. blenoides, the length frequency distribution clearly separates the juveniles from the adults indicating a seasonal recruitment, but this is a common feature of many deep-sea fish and invertebrates (Gordon et al., 1995).

This is the first morphological study of the gonads of P. blennoides, M. moro and L. lepidion. The histological results of the reproductive systems of these three species of gadiforms seem to indicate that they are very similar. Cystic spematogenesis was observed in P. blennoides and M. moro, as previously in the North Atlantic specimens of $C$. rupestris (Alekseyeva et al., 1992). Testicular aplasia had been described in Merluccius hubbsi (Louge and Christiansen, 1992). In the present study immature testes also had a large amount of connective tissue, as shown in the cod aplasia. Some intratesticular oocytes were observed in $P$. blennoides. Many fishes go through a prematura- tional sex change, differentiating but not maturing first as females, with some individuals later changing to males (Shapiro, 1992).

In deep-sea gadiforms, the histological characteristics of the ovaries have only been described in $C$. rupestris (Alekseyeva et al., 1992; Kelly et al., 1996), Macrourus berglax (Eliassen and FalkPetersen, 1985; Murua and Motos, 2000), and partially in Nezumia stelgidolepis (Hoff et al., 2000). The fourth stages of development described here for $P$. blennoides, $M$. moro and L. lepidion are homologous at the first stages described in the above mentioned species. However, oil drop coalescence and hydrated oocytes seem to escape our sampling since the mature oocytes measured in the present study were around $300 \mu \mathrm{m}$ and hydrated oocytes in these macrourids were bigger than $1.6 \mathrm{~mm}$.

Gravid females (stage IV) had only $24 \%$ of vitellogenic oocytes for $P$. blennoides and $6 \%$ for $M$. moro, revealing that oocytes did not exhibit synchronous development. Whether these species are all-at-once or batch-spawners as described in other deep-sea gadiforms (Eliassen and Falk-Petersen, 1985; Alekseyeva et al., 1992; Kelly et al., 1996; Murua and Motos, 2000; Allain, 2001) is hard to conclude since the samples belong to different stocks and different years due to their difficulty of extraction.

In conclusion, the shallowest studied species, $P$. blennoides, shows a seasonal pattern and females seem to be all-at-once spawners while the deepests species, M. moro and L. lepidion, living in a stable and oligotrophic medium, show a quasi-continous reproductive pattern and their females seem to be batch-spawners. Hence, for these species the physical constancy at greater depths is able to lengthen the reproductive season in the Mediterranean deepsea. The deep-sea adaptations include ecological and ethological issues, but the main similarities observed between the morphology of their gonads and the gonads of their shallow-water congeners suggest Grassle's hypothesis (1994) that phylogenetic constraints affect reproduction more than deep-sea adaptations.

\section{ACKNOWLEDGEMENTS}

This paper is a result of the Spanish CICYT Projects RETRO (MAR90-757), ZONAP (PB90-O166) and BATMAN (AMB93/0283) and the European Commission project EU FAIR (CT 95-0655). The 
authors would like to thank Drs. P. Abelló, M. Ballesteros, A. Bozzano, J.E. Cartes, J.B. Company, L. Dantart, D. Lloris, F. Maynou, P. Torres, J. Rucabado, C. Ruíz-Altaba and C. Stefanescu for their help during sampling cruises, the Captains and crews of R/V "García del Cid", F/V "La Blava" and F/V "Bonamar”, Ms. E. García and S. Palenzuela for their technical support, Dr. R.I. Ochoa and R. Torres for their histological support, and F. Maynou for providing Figure 1.

\section{REFERENCES}

Albert, O.T., E.M. Nilssen, A. Stene, A.C. Gundersen and K.H. Nedreaas. - 2001. Maturity classes and spawning behavior of Greenland halibut (Reinhardtius hippoglossoides). Fish. Res. 51: $217-228$

Alekeseyeva, F.Y., Y.I. Alekeseyev and A.N. Zakharov. - 1992 Vitellogenesis, nature of spawning, fecundity, and gonad maturity stages of the roundnose grenadier, Coryphaenoides rupestris, in the North Atlantic. J. Ichthyol., 33: 32-45.

Allain, V. - 2001. Reproductive strategies of three deep-water benthopelagic fishes from the northeast Atlantic Ocean. Fish. Res., 51: $165-176$.

Atkinson, D. B. - 1995. The biology and fishery of roundnose grenadier (Coryphaenoides rupestris Gunnerus, 1765) in the north west Atlantic. In: Hopper, A. G. (ed.), Deep-water fisheries of the north Atlantic oceanic slope, pp. 51-111. Netherlands: Kluwer Academic Publishers.

Bergstad, O.A. - 1990. Distribution, population structure, growth and reproduction of roundnose grenadier Coryphaenoides rupestris (Pisces: Macrouridae) in the deep waters of the Skagerrak. Mar. Biol., 107: 25-39.

Bowering, W. R. and W.B. Brodie. - 1995. Greenland halibut (Reinhardtius hippoglossoides). A review of the dynamics of its distribution and fisheries off eastern Canada and Greenland. In A.G. Hopper, (ed.), Deep-water fisheries of the north Atlantic oceanic slope, pp. 114-160. Netherlands: Kluwer Academic Publishers.

Carrasson, M., J. Matallanas and M. Casadevall. - 1997. Feeding strategies of deep-water morids on the western Mediterranean slope. Deep-sea Res., 44(9-10): 1685-1699.

Clark, M. - 1995. Experience with the management of orange roughy (Hoplostethus atlanticus) in New Zealand, and the effects of commercial fishing on stocks over the period 1980 1993. In: Hopper, A. G. (ed.), Deep-water fisheries of the north Atlantic oceanic slope, pp. 251-266. Netherlands: Kluwer Academic Publishers.

Clark, M. - 2001. Are deepwater fisheries sustainable? - the example of the orange roughy (Hoplostethus atlanticus) in New Zealand. Fish. Res., 51: 123-135.

Cohen, D. M. - 1986. Family Moridae. In: P. J. P. Whitehead, M.L. Bauchot, J.C. Hureau, J. Nielsen and E. Tortonese (eds.). Fishes of the north-eastern Atlantic and the Mediterranean, pp. 713-723. Bungay: UNESCO

Cohen, D. M., T. Inada, T. Iwamoto and N. Scialabra. - 1990. Gadiform fishes of the world (Order Gadiformes). An annotated and illustrated catalogue of cod, hake, grenadiers, and other gadiform fishes known to date. FAO Fisheries Synopsis, 10: 1442.

Coggan, R.A., J.D.M. Gordon and N.R. Merrett. - 1999. Aspects of the biology of Nezumia aequalis from the continental slope west of the British Isles. J. Fish Biol., 54: 152-170.

D’Onghia, G., A. Tursi, P. Maiorano, A. Matarrese and M. Panza. - 1998. Demersal fish assamblages from the bathyal grounds of the Ionian Sea (middle-eastern Mediterranean). Ital. J. Zool., 65, suppl.: 287-292.

D’Onghia, G., M. Basanisi, A. Matarrese and F. Megli. - 1999. Reproductive strategies in macrourid fish: seasonality or not? Mar. Ecol. Prog. Ser., 184: 189-196.

D’Onghia, G., M. Basanisi and A. Tursi. - 2000. Population struc- ture, age and growth of macrourid fish from the upper slope of the Eastern-Central Mediterranean. J. Fish Biol., 56: 12171238.

Eliassen, J. E. and I.B. Falk-Petersen. - 1985. Reproductive biology of the roughhead grenadier (Macrourus berglax Lacepède) (Pisces, Gadiformes) from the continental slope of northern Norway. Sarsia, 70: 59-67.

Gage, J. D. and P.A. Tyler. - 1991. A natural history of organisms at the deep-sea floor. Cambridge: Cambridge University Press.

Gallardo, M. - 1980. Características biológicas de Phycis blennoides (Brünnich, 1968) con especial referencia a algunas modificaciones debidas al efecto de la explotación pesquera. $\mathrm{PhD}$. Thesis. Univ. de Barcelona.

Gordon, J.D.M. - 1979. Seasonal reproduction in deep-sea fish. In: E. Naylor and R.G. Hartnoll (eds.), Cyclic phenomena in marine plants and animals, pp. 223-229. Oxford, Pergamon Press.

Gordon, J. D. M. and J.A.R. Duncan. - 1985. The biology of fish of the family Moridae in the deep-water of the Rockall trough. $J$. mar. biol. Ass. U.K., 65: 475-485.

Gordon, J. D. M., N.R. Merrett and R.L. Haedrich. - 1995. Environmental and biological aspects of slope dwelling fishes of the north Atlantic. In: A.G. Hopper, (ed.), Deep water fisheries of the North Atlantic Oceanic Slope, pp. 1-26. Dordrecht: Kluwer Academic Publishers.

Grassle, J. F. - 1994. Ecological Patterns in the deep-sea benthos: How are they related to reproduction, larval biology, and recruitment? In: C.M. Young and K.J. Eckelbarger (eds.). Reproduction, larval biology, and recruitment of the deep-sea benthos, pp. 306-314. New York.

Gundersen, A.C., J.E. Ronnerberg and J. Boje. - 2001. Fecundity of Greenland halibut (Reinhardtius hippoglossoides Walbaum) in East Greenland waters. Fish. Res., 51: 229-236.

Helfman, G. S., B.B. Collette and D.E. Facey. - 1997. The diversity of fishes, Malden: Blackwell Science.

Hoff, G.R., T.W. Buckley, J.C. Drazen and K.M. Duncan. - 2000. Biology and ecology of Nezumia liolepis and N. stelgidolepis from the west coast of North America. J. Fish Biol., 57: 662680.

Hopkins, T. S. - 1984. Physics of the Sea. In: R. Margalef (ed.). Western Mediterranean, pp. 100-125. Barcelona: Pergamon Press.

Kelly, C.J., P.L. Connolly and J.J. Bracken. - 1996. Life histories and reproduction. Maturity, oocyte dynamics and fecundity of the roundnose grenadier from the Rockall Trough. J. Fish Biol., 49(Supplement): 5-17.

Koslow, J.A., J. Bell, P. Virtue and D.C. Smith. - 1995. Fecundity and its variability in orange roughy: effects of population density, condition, egg size, and senescence. J. Fish Biol., 47: $1063-1080$

Koslow, J.A., G.W. Boehlert, J.D.M. Gordon, R.L. Haedrich, P. Lorance and N. Parin. - 2000. Continental slope and deep-sea fisheries: implications for a fragile ecosystem. ICES J. Mar. Sci., 57: 548-557.

Lo Bianco, S.E. - 1909. Notizie biologique riguardanti specialmente il periodo di maturità sessuale degli animali del Golfo di Napoli. Mitth Zool Stat Neapel , 19: 1-513.

Louge, E.B. and H.E. Christiansen. - 1992. Aplasia testicular en merluza Merluccius hubbsi. Atlántica, Río Grande, 4: 121-127.

Macpherson, E. - 1978. Régimen alimentario de Phycis blennoides (Brünnich) y Antonogadus megalokinodon (Kolombatovic) (Pisces:Gadidae) en el Mediterráneo Occidental. Invest. Pesq., 42: 455-466.

Magnússon, J.V. - 2001. Distribution and some other biological parameters of two morid species Lepidion eques (Günther, 1887) and Antimora rostrata (Günther, 1878) in Icelandic waters. Fish. Res., 51: 267-281.

Magnússon, J.V. and J. Magnússon. - 1995. The distribution, relative abundance, and biology of the deep-sea fishes of the Icelandic slope and Reykjanes ridge. In: A.G. Hopper (ed.). Deepwater fisheries of the north Atlantic oceanic slope, pp. 161-199. Netherlands: Kluwer Academic Publishers.

Massutí, E., B. Morales-Nin and C. Stefanescu. - 1995. Distribution and biology of five grenadier fish (Pisces: Macrouridae) from the upper and middle slope of the northwestern Mediterranean. Deep-Sea Res., 42(3): 307-330.

Massutí, E., B. Morales-Nin and D. Lloris. - 1996. Bathymetric distribution and recruitment patterns of Phycis blennoides (Pisces: 
Gadidae) from the slope of the northwestern Mediterranean. Sci. Mar., 60(4): 481-488.

Matarrese, A., G. D'Onghia, M. Basanisi and F. Mastrototaro. 1998. Spawning and recruitment of Phycis blennoides (Phycidae) from the north-western Ionian Sea (Middle-eastern Mediterranean). Ital. J. Zool., 65: 203-209.

Meer, H. J. van der and G. Ch. Anker. - 1984. Retinal resolving power and sensitivity of the phototopic system in seven Haplochromine species (Teleostei, Cichlidae). Netherlands J. Zool., 34: 197-209.

Merrett, N. R. and R.L. Haedrich. - 1997. Deep-sea demersal fish and fisheries, London: Chapman \& Hall.

Morales-Nin, B. - 1990. A first attemp at determining growth patterns of some Mediterranean deep-sea fishes. Sci. Mar., 54(3): 241-248.

Morales-Nin, B., E. Massutí and C. Stefanescu. - 1996. Distribution and biology of Alepocephalus rostratus from the Mediterranean Sea. J. Fish Biol., 48: 1097-1112.

Moranta, J., C. Stefanescu, E. Massutí, B. Morales-Nin and D. Lloris. - 1998. Fish community structure and depth-related trends on the continental slope of the Balearic Islands (Algerian basin, western Mediterranean). Mar. Ecol. Prog. Ser., 171: 247259.

Munk, O. - 1965. Omosodium lowei Gunther, 1887. A bathypelagic deep-sea fish with an almost pure-cone retina. Vidensk Meddr dansk naturh Foren, 128: 341-355.

Murua, H. and L. Motos. - 2000. Reproductive biology of roughhead grenadier (Macrourus berglax Lacepède, 1801) (Pisces, Macrouridae), in Northwest Atlantic waters. Sarsia, 85: 393402.
Orton, J.H. - 1920. Sea temperature, breeding and distribution in marine animals. J. Mar. Biol. Ass. U.K., 12: 339-366.

Puig, P., J.B. Company, F. Sardà and A. Palanques. - 2001. Responses of deep-water shrimp populations to intermediate nepheloid layer detachments on the Norrthwestern Mediterranean continental margin. Deep-Sea Res. I, 48: 1-13.

Shapiro, D.Y. - 1992. Plasticity of gonadal development and protandry in fishes. J. Exp. Zool., 261: 194-203.

Stefanescu, C., J. Rucabado and D. Lloris. - 1992a. Deep-living demersal fishes in the Catalan Sea (western Mediterranean) below a depth of 1000 m. J. nat. Hist., 26: 197-213.

Stefanescu, C., J. Rucabado and D. Lloris. - 1992b. Depth-size trends in western Mediterranean demersal deep-sea fishes. Mar. Ecol. Prog. Ser., 81: 205-213.

Svetovidov, A.N. - 1986. Family Gadidae. In: P.J.P. Whitehead, M.L. Bauchot, J.C. Hureau, J. Nielsen and E. Tortonese (eds.) Fishes of the North-eastern Atlantic and Mediterranean, Vol. 1. 680-710 pp. UNESCO, Bungay.

Tyler, P.A., L.S. Campos-Creasey and L.A. Giles. - 1994. Environmental control of quasi-continuous and seasonal reproduction in deep-sea benthic invertebrates. In: C.M. Young and K.J. Eckelbarger (eds.). Reproduction, larval biology, and recruitment of the deep-sea benthos, pp. 158-178. New York: Columbia University.

Young, C.M. and K.J. Eckelbarger. - 1994. Reproduction, larval biology, and recruitment of the deep-sea benthos. New York: Columbia University, Columbia University.

Scient. ed.: P. Oliver 